\title{
Pharmacogenetics and Pharmacogenomics of Colorectal Cancer: Moving Towards Personalized Medicine
}

\author{
Joseph Ciccolini1 $1,2,3$, Fréderic Fina ${ }^{2,3}$, \\ L'Houcine Ouafik ${ }^{2,3}$ and Bruno Lacarelle ${ }^{1,3}$ \\ ${ }^{1}$ APHM, University-Hospital Timone, \\ Laboratoire de Pharmacocinétique et Toxicocinétique, Marseille, \\ ${ }^{2} A P H M$, University-Hospital Nord, \\ Laboratoire de Transfert d'Oncologie Biologique,, Marseille, \\ ${ }^{3}$ Aix-Marseille Univ, CRO2 UMR 911, Marseille,
}

France

\section{Introduction}

Colorectal cancer (CRC) remains one of the most deadly diseases in the western world, and starts to become a concern in developed countries (Labianca et al., 2010). However, significant steps have been made recently in CRC therapy. Until the 80's, 5-fluorouracil (5FU) was the only available drug to treat patients, with limited efficacy. Today, 4 cytotoxic agents (5-FU associated with folinic acid, capecitabine, oxaliplatin, irinotecan) and three monoclonal antibodies (cetuximab, panitumumab, bevacizumab) are available, mostly as part of combinations (Koutras et al., 2011). In particular, the rise of targeted therapies in digestive oncology has fueled a new hope by significantly stretching the therapeutic options available so far. Despite these improvements, treatment of metastatic CRC (mCRC) remains a challenging task, and it is acknowledged now that although improving response rates, the introduction of the latest targeted therapies only marginally impacts on either progression free survival (PFS) or overall survival (OS) of mCRC patients. Because of the cost of these new therapies, identifying biomarkers likely to sort patients on their ability to benefit or not, from these new drugs is paradigmatic of the current trend to move towards a more personalized medicine in oncology. Because genetic variability is one of the main factor regulating efficacy and toxicity of most anticancer agents, addressing the issues of pharmacogenomics and pharmacogenetics (PGX) in CRC patient becomes critical, far beyond the only use of costly targeted therapies. Although often used interchangeably, the term "pharmacogenetics" refers historically to inherited changes in genes coding for drug metabolizing enzymes or membrane transporters, thus impacting on the pharmacokinetic (PK) profile and exposure levels eventually, whereas "pharmacogenomics" is a broader definition encompassing genetic changes at the tumor level potentially affecting drug response (Amstutz et al., 2011). Whether they are somatic or found in the germline, all these mutations can potentially have deleterious impacts on the clinical outcome of patients with CRC cancer. At the tumor level, genetic changes affecting the expression of pharmacological 
targets or downstream signaling pathways can lead to treatment failure, as highlighted by the now canonical KRAS mutational status in patients undergoing anti-EGFR therapies. Constitutive mutations are mostly associated with increased toxic risk, as largely publicized by the dihydropyrimidine dehydrogenase (DPD) deficiency syndrome, a condition that puts 5-FU patients at risk of life-threatening toxicities. Of note, when not directly life-threatening, inherited genetic mutations affecting drug disposition in the body and pharmacokinetics can ultimately lead to treatment failure too, because the induced-toxicities often require discontinuation of the treatments until the patient recovers. For all these reasons, developing pharmacogenetic and pharmacogenomic testing in routine clinical practice is now seen as a major issue in oncology.

\section{Pharmacogenomics: A matter of life $\&$ death at the tumor level}

\subsection{Cytotoxics: Why should we not forget that they are targeted therapies too}

Standard care of colorectal cancer includes the use of a variety of cytotoxic agents, used either alone or more frequently as part of combinations (e.g., the canonical Folfiri and Folfox4 regimen). Each of these drugs have their own specific target (e.g., thymidylate synthase for 5-FU, DNA for oxaliplatin, topoisomerase I for irinotecan) and in this respect, numerous studies have focused on the deregulations affecting these targets, either at the genetic or the molecular level, as an attempt to predict treatment efficacy. Indeed, variations in the expression level of the targeted protein, polymorphisms inducing conformation changes, or increase in the repair systems/salvage pathways have been identified as major causes for treatment failure in $\mathrm{mCRC}$ patients.

\subsubsection{5-FU \& Oral 5-FU: The older, the better}

5-FU remains the pivotal drug for treating CRC. Initially used alone, it soon turned to be systematically associated with folinic acid so as to enhance its effect as an antimetabolite, before being introduced as the backbone of several polychemotherapies including irinotecan (a.k.a. Folfiri regimen) or oxaliplatin (a.k.a. Folfox regimen). 5-FU's main target is thymidylate synthase (TS), an enzyme essential to the DNA synthesis and cell replication. Several genetic polymorphisms can affect both TYMS, the gene coding for TS, and the folate cycle necessary for the synthesis of methylene tetrahydrofolate, the cofactor required for a complete inhibition of the target through the formation of a stable ternary complex between the enzyme, the cofactor, and fluorodeoxyuridine monophosphate (FdUMP). TS overexpression in tumors is generally associated with resistance to 5-FU treatment, both in vitro and at the bedside (Popat et al., 2004, Lenz et al., 2004). Conversely, another pivotal study has demonstrated that higher TS expression was predictive of higher response with adjuvant fluoropyrimidine (Edler et al., 2002). However, other clinical reports failed in demonstrating such relationship (Locker et al., 2006, Lurje et al., 2009), thus preventing substantial step to be undertaken for implementing screening for TS expression in tumors in routine clinical practice. Variations in TS expression are, at least in part, related to mutations affecting the TYMS gene promoter. For instance, the TSER $* 3$ genotype has been associated with increased mRNA production, thus potentially leading to lower response rates in mCRC patients treated with 5-FU (Uetake et al., 1999). Beside the issue of over-expressing TS tumors likely to resist to 5-FU, constitutive polymorphisms in the $5^{\prime}$ and $3^{\prime}$ UTRs of the TYMS gene responsible for downregulation of TS, have been associated with increased toxicities in patients treated with 5-FU or oral capecitabine (Larguiller et al., 2006). However, 
as for TS expression level in tumors, the actual clinical relevance of these polymorphisms is far from being consensual. Lower response rates have been reported in colorectal cancer patients with the TS 5'-UTR 3R genotypes (ie, TSER ${ }^{\star} 3$ ), as compared to individuals harboring the homozygous TS 5'-UTR 2R/2R genotype (Salgado et al., 2007). Of note, other groups (Stoehlmacher et al., 2004, Kostopoulos et al., 2009) failed in observing any significant difference in the clinical outcome according to the TS 5'-UTR genotypes, whereas conversely, other authors (Jakobsen et al., 2005; Dotor et al., 2006) found longer survival in carriers of TS 5'UTR 3R genotypes as compared with those carrying the TS 5'-UTR $2 R / 2 R$ genotypes. Such conflicting results for predicting outcome from TYMS genomic status is not surprising. Several factors such as genetic and epigenetic regulations may interfere with the genotype-tophenotype relationships (Pullmann et al., 2006). For instance, the loss of heterozygosity in tumours at the TS locus may cause the heterozygous TS 5'-UTR $2 \mathrm{R} / 3 \mathrm{R}$ risk genotype to acquire either the $2 \mathrm{R} /$ loss or the $3 \mathrm{R} /$ loss genotype. Consequently, individuals theoretically at risk of treatment failure on the basis of their TS 5'-UTR 2R/3R genomic status may harbor actually the favorable $2 \mathrm{R} /$ loss genotype in cancer cells and exhibit higher response eventually when treated with 5-FU (Ruzzo et al., 2007). In addition to target TS, other non-synonymous SNPs (677C>T: MTHFR*4 and 1298A>C:MTHFR*6 allelic variants) affecting methylene tetrahydrofolate reductase (MTHFR), one of the key-enzyme involved in the synthesis of reduced folate cofactor, could lead to lack of efficacy when down-regulated (Etienne-Grimaldi et al., 2007, Zintsaras et al., 2009, Braun et al., 2009). However, as for TYMS, the actual impact of MTHFR genetic polymorphisms on the clinical outcome with 5-FU or 5-FU-derivatives remains to be fully elucidated because inconsistent data have been generated so far (Sharma et al., 2008, Ruzzo et al., 2007). All these contradictory findings with TYMS and the associated MTHFR genomic status are better understood when one keeps in mind that TS is not the main locus of action of 5-FU. Incorporation into RNA and DNA can be alternative mechanisms of actions for the cytotoxic effects of 5-FU, depending on the way the drug will be metabolized within tumor cells (Ciccolini et al., 2000a). In this respect, the expression levels of activating/deactivating enzymes at the tumor level (eg, orotate phosphoribosyl transferase, thymidine kinase, thymidine phosphorylase, dihydropyrimidine dehydrogenase) have been associated with clinical outcome in patients treated with 5-FU-containing regimen, although once again the data collected so far proved to be rather conflicting (Ciccolini et al., 2004; Soong et al., 2008). For instance, thymidine kinase is implicated both in the activation of 5-FU to active metabolite FdUMP with subsequent theoretical better TS inhibition if highly expressed, and in the de novo salvage pathway likely to help cancer cells to survive to 5-FU-induced thymineless stress (Fanciullino et al., 2007). Similarly, thymidine phosphorylase (TP) is involved in the tumoral activation of both 5-FU and capecitabine, but could promote neoangiogenesis too, thus rendering the clinical impact of TP levels in tumors hardly predictable (Ciccolini et al., 2004). Furthermore, deregulation of downstream proteins involved in the transmission of apoptosis in cells exposed to thymineless stress can affect 5-FU or capecitabine antiproliferative efficacy, despite proper inhibition of target TS. Because 5-FU exerts its cytotoxic effects partly through a p53/Fas-dependent apoptotic pathway involving Bax translocation and mitochondrial permeabilization, deregulations affecting each of these steps can interfere with the actual upstream TYMS status or the extent of TS inhibition (Borralho et al., 2007). For instance, down-expression of Apo-1 Fas CD95 receptor has been associated with resistance to 5-FU or capecitabine in non-clinical colorectal models, including after that a near-total inhibition of TS activity was achieved (Ciccolini et al., 2000b; 2001). 
However, subsequent clinical studies failed in demonstrating the role Fas expression could play as a predictive marker in patients with colorectal cancer (Backus et al., 2001; Bezulier et al., 2003).

\subsubsection{Oxaliplatin: A metal precious to the patients}

In clinical practice, oxaliplatin is given in mCRC patients in association with 5-FU/folinic acid, a combination known as the Folfox regimen. It can be further combined now with the latest monoclonal antibodies targeting VEGF or EGFR-1. Oxaliplatin is a third-generation platinum derivative that targets complementary DNA strands, thus inducing cell death eventually. However, the nucleotide excision repair (NER) system is designed to remove the oxaliplatin-induced DNA-adducts, and several factors (XPD (a.k.a. ERCC2), XPC and XPA) are implicated in the repair process of DNA helixes once adducts have been formed. In addition, XPG and ERCC1 are implicated in the cleavage of the damaged DNA strand and participate to the repairing pattern of cells exposed to oxaliplatin. Any changes in those repair mechanisms can lead to increase of sensitivity or loss of efficacy in patients. Several genotypes at the tumor level have been associated with clinical outcome in oxaliplatinregimen. In particular, it has been demonstrated that polymorphisms affecting ERCC1 and XPD genes are related to patient survival. For instance, ERCC1-118 T/T, or XPD-751 A/C and $\mathrm{C} / \mathrm{C}$ genotypes have been associated with reduced disease-free survival in patients treated with oxaliplatin (Ruzzo et al., 2007). In another study, the Lys751Gln polymorphism of the XPD gene has been identified as a predictive marker in $\mathrm{mCRC}$ patients undergoing FolFox treatment (Le Morvan et al., 2007). Beside the NER, basepair excision repair is also involved in the chemosentivity to oxaliplatin. XRCC1 gene is affected by several polymorphisms, and expression of the wild-type allele has been associated with better clinical outcome in patients with mCRC (Suh et al., 2006, Stoehlmacher et al., 2001), although subsequent studies failed in confirming the relevance of establishing XRCC1 genotype as a predictive biomarker with oxaliplatin (Ruzzo et al., 2007). Along with the issue of efficacy, mutations affecting Glutathione-S Transferase (GST), the enzyme responsible for the cell detoxification of oxaliplatin, could have an impact on the clinical outcome with oxaliplatin. Overexpression of tumoral GSTP1 has been found in CRC patients, thus leading to lack of efficacy (Glasgow et al., 2005). However, the exact role the genetic status GSTP1 plays in patients treated with oxaliplatin remains controversial. For instance, the GSTP1 ile105val genotype has been associated with improved survival in patients treated with Folfox regimen (Stoehlmacher et al., 2002), although the same genotype was predictive of reduced survival in another study (Sun et al., 2005) . In addition, the GSTP1-105 G allele, could explain higher incidence of severe neurotoxicities, the most common side-effect of oxaliplatin, observed in some patients (Ruzzo et al., 2007). Another polymorphism affecting the AGXT gene coding for the enzyme responsible for the metabolism of oxalate, which peaks during oxaliplatin infusion, could explain higher risk of neurotoxicity in patients (Gamelin et al., 2007).

\subsubsection{Irinotecan: Twist again 'till double-strand DNA breakage}

Irinotecan (CPT-11) is a topoisomerase-I (Topo-1) inhibitor usually combined with 5$\mathrm{FU} /$ folinic acid regimen, an association known as the FolFiri regimen. Topo-1 relieves torsional strain in DNA, thus allowing DNA replication, recombination, and repair. Irinotecan prevents religation of the DNA strand by binding to topoisomerase I-DNA 
complex, thus causing double-strand DNA breakage and cell death eventually. Expression levels of target topo-I has been associated with clinical outcome in multivariate analysis performed from large studies including several hundreds of patients undergoing irinotecanbased therapy (Braun et al., 2008; Kostopoulos et al., 2009). However, the lack of randomized, prospective trial prevents, for the time being, the evaluation of Topo-1 level in tumours to be proposed in routine clinical setting as a predictive biomarker for irinotecan efficacy, and little is known about the genetic or epigenetic events affecting the Topo- 1 gene likely to modify expression levels of the target protein. However, in the Focus trial, Topo-1 expression level was found to be related to efficacy, although it remains unclear whether the expression level is to be considered as a predictive or a prognostic marker (Braun et al., 2008). In addition, as for oxaliplatin, deregulations affecting DNA-repairing enzymes like XRCC1, ERCC1 and GSTP1 have been found to be predictive of the clinical outcome in irinotecan-treated patients. Polymorphism affecting the XRCC1 gene (eg, the GGCC-G haplotype) was associated with improved response rates in patients given irinotecan, much probably in relation with loss of ability to repair DNA damage (Hoskins et al., 2008). Conversely, better response and, in some cases, improved PFS was observed in patients undergoing FolFiri regimen with tumors overexpressing GSTP1 and ERCC1 (Vallbohmer et al., 2006). This finding may be confusing because higher expression in DNA-repair enzymes is normally associated with resistance to DNA-targeting agents. Here, high ERCC1 levels could be indicative of a higher DNA damage, thus making the tumor cells more sensitive to Topo-I inhibition by irinotecan. In the same study, EGFR expression was found to be associated too with better response, although to date, no molecular mechanisms underlying this observation have been found.

\subsection{Biotherapies: Where are my keys?}

Treatment of colorectal cancer has taken benefit from the rise of the biotherapies in clinical oncology, because both anti-VEGF and anti-EGFR monoclonal antibodies can be used now in association with cytotoxics agents. However, the efficacy of most targeted therapies is generally contingent upon a number of biomarkers at the tumor level to be checked.

\subsubsection{Anti-EGFR monoclonal antibodies: Why hitting the target is not enough}

Cetuximab and panitumumab are two anti-Her1 monoclonal antibodies indicated for treating metastatic colorectal cancer. Initially proposed alone, both drugs showed better efficacy and improved survival when combined with standard Folfox4 or Folfiri regimen. Although cetuximab is a chimeric IgG1 and panitumumab a 100\% human IgG2, these both antibodies target the extracellular domain of EGFR-1, thus blocking the downstream signaling pathway normally leading to cell proliferation and differenciation, neoangiogenesis and invasion patterns associated with colorectal cancer. Cetuximab and panitumumab prescription is contingent upon the completion of pharmacogenomics testing. Expression level of target EGFR is the first condition, although in clinical practice, the relevance of this test is more and more debated and controversial at the bedside. However, several studies have demonstrated how patients with elevated EGFR gene copy number are more likely to respond to cetuximab or panitumumab therapy (Moroni et al., 2005; SartoreBianchi et al., 2007, Heinemann et al., 2009). More interestingly and consensual, determination of the mutational status of KRAS soon turned to be the paradigm of implementing pharmacogenomic testing prior to initiating treatment with a targeted 
therapy. The EGFR/KRAS/Raf pathway is implicated in signal transduction from receptors to the nucleus, thus promoting cell proliferation and differentiation. KRAS transmits signal after binding to guanosine triphosphate (GTP), and becomes inactive when GTP is converted to GDP. Mutations affecting KRAS will maintain the protein continuously activated in a switch-on position, even if the upstream receptor is inhibited by a monoclonal antibody. It was demonstrated in the mid-2000's that specific KRAS mutations (eg, codons 12/13) was associated with lack of response in cetuximab-treated patients (Lievre et al., 2006). Subsequent studies all confirmed the predictive value of wild-type (WT) KRAS for the response with anti-EGFR biotherapies, either cetuximab or panitumumab, regardless of their use as monotherapy or combined with cytotoxics (Heinemann et al., 2009, Asghar et al., 2010). However, WT KRAS is a mandatory but no sufficient condition to guarantee an optimal efficacy with anti-EGFR therapies. Mutations affecting BRaf, an effector of KRAS, has been associated with treatment failure, although it remains unclear whether BRaf mutational status should be used as a prognostic or a predictive marker (Di Nicolantonio et al., 2008). Similarly, correlation was found in cetuximab-treated patients between EGFR gene amplification, WT KRAS status, PTEN expression, and response. Of note, loss of PTEN expression was systematically associated with treatment failure, thus suggesting that PTEN could be a novel predictive biomarker for anti-EGFR therapies (Frattini et al., 2007). Along with PTEN, several other parameters like epiregulin and amphiregulin expression have been recently identified as putative biomarkers (Jacobs et al., 2009; Laurent-Puig et al., 2009; Di Fiore et al., 2010), although larger prospective studies will be necessary to validate their clinical relevance to predict clinical outcome with EGFR-inhibitors.

\subsubsection{Anti-VEGF therapy: Desesperatly seeking biomarkers}

Bevacizumab is the only stricto-sensu antiangiogenic therapy approved for treating mCRC patients in association with cytotoxics. This humanized monoclonal antibody targets circulating VEGF-A. To date, no predictive biomarkers have been identified with bevacizumab. Overexpression of VEGF is usually associated with poor survival in mCRC patients, but VEGF level is generally considered as a prognostic, rather than a predictive, biomarker. Even in a prognostic setting, the actual role VEGF polymorphism plays remains unclear. For instance, in some studies, the -460CC genotype was found to have a favorable impact on OS in gastric cancer patients (Kim et al., 2007), but deleterious in breast cancer patients ( $\mathrm{Lu}$ et al., 2005). Beside, some studies in breast cancer patients have found a relationship between VEGF polymorphisms (eg, -2578A/A and -1154A/A genotypes) and better survival in patients treated with the paclitaxel + bevacizumab regimen (Schneider et al., 2008). Similar relationship between VEGF-A polymorphism and both toxicity and DFS has been evidenced more recently (Etienne-Grimaldi et al., 2010). A similar trend has been found with digestive cancers (Formica et al., 2010). Additionally, circulating PDGF could be implicated in resistance to anti-angiogenic drugs (Crawford et al., 2009), as well as SDF1 and FGF2 factors (Batchelor et al., 2007). Finally, plasma cytokines and vascular factors could be associated with clinical outcome in patients undergoing bevacizumab-based therapy (Kopetz et al., 2010). However in a recent study, Loupakis et al. have investigated the molecular and genetic markers likely to predict efficacy in mCRC patients treated with the Folfoxiri plus bevacizumab quadruple combination. Among the various bevacizumabrelated biomarkers they monitored in plasma (ie VEGF, PIGF, sVEGFR2, TSP-1 plasma level) and the screening of several polymorphims affecting VEGF (eg., -2578C/A, -1498C/T, $-1154 \mathrm{G} / \mathrm{A}, 936 \mathrm{C} / \mathrm{T})$ and VEGFR-2 (-604A/G, 1192C/T, 1719T/A), little relevant association 
with PFS was found (Loupakis et al., 2011). This latter study illustrates the difficulty in identifying relevant biomarkers for response in heavily treated $\mathrm{mCRC}$ patients receiving several drugs in a row, the observed efficacy being the resulting combination of the numerous parameters affecting each drug.

\section{Pharmacogenetics: When genetics help finding the right exposure}

\subsection{Cytotoxics: Improving the efficacy/toxicity balance}

Beside those affecting tumors, several constitutive genetic mutations can impact on the disposition of anticancer drugs, especially when they concern genes coding for detoxifying enzymes in the liver. Although for years, such polymorphisms were mostly associated with increased risk of developing severe and sometimes deadly toxicities upon drug intake, they may impact as well on treatment efficacy eventually. Indeed, when they are not directly lifethreatening, drug-induced toxicities and their management often require treatment discontinuation, delays in subsequent radiotherapy courses if scheduled, with a subsequent loss of chance and poor clinical outcome eventually.

\subsubsection{5-FU \& Oral 5-FU}

Fluoropyrimidines pharmacokinetics is primarily dependent upon an intense liver first pass effect mediated by dihydropyrimidine dehydrogenase (DPD), the enzyme that converts uracil into dihydrouracil. It is generally estimated that about $90-95 \%$ of an administered 5FU dose will be metabolized in the liver before being distributed throughout the body. DPD exhibits a similar pivotal role in the disposition of oral fluoropyrimidines like capecitabine or UFT, all generating 5-FU eventually. DPYD gene is highly polymorphic because several dozen of mutations have been described thus far (Van Kuilenburg, 2004). Mutational inactivation of the DPYD gene has been characterized as an autosomal recessive disease in Caucasians' population, with probably a higher impact in black American (Mercier C et al., 2006). Genetic and epigenetic regulations, such as promoter hypermethylation or variations in transcriptional factor expression, could play as well a critical role in DPYD dysregulations (Etienne MC et al., 1994, Zhang et al., 2006), although this issue remains debated today. Admittedly, three relevant mutations (canonical IV14+1G>A (DPYD*2A), plus 2846A>T, and $1679 \mathrm{~T}>\mathrm{G}$ ) should be screened at bedside to anticipate 5-FU-related side effects (Morel et al., 2006). Numerous clinical reports have demonstrated the deleterious effect of DPD genetic polymorphism in patients undergoing 5-FU based regimen. Regardless of the upstream genetic events leading to the loss of enzymatic activity, impaired DPD has been systematically associated with increased risk of developing severe/lethal toxicities upon 5FU exposure. In a proof-of-concept study, DPD deficiency was retrospectively identified as the culprit for $70 \%$ of the severe toxicities and $80 \%$ of the toxic-death cases monitored over a two-year observation period, and when performed, drug monitoring confirmed strong overexposure to 5-FU in DPD-deficient individuals (Ciccolini et al., 2006). However, some reports failed in providing data for this pivotal role DPYD genetic polymorphism could play in the incidence of severe toxicities with 5-FU. In a gene-candidate study, Schwab et al. have investigated the role several polymorphisms, including the DPYD*2A allelic variant, could play in the tolerance to 5-FU. Surprisingly, this genotype was found to be only marginally associated with toxicities, but it has to be underlined that in this study, no complementary functional investigations were undertaken to evaluate globally the DPD status in those 
patients (Schwab et al., 2008). In addition to 5-FU, several reports have suggested that DPYD genetic polymorphism could be an issue with capecitabine too. The very first toxic-death case has been first observed in the late-2000' in a patient treated with capecitabine who was found to be profoundly DPD deficient after post-mortem investigations (Mercier et al., 2007a). Several other clinical reports have demonstrated how DPYD genetic polymorphism could put deficient patients at risk of experiencing severe toxicities if given capecitabine (Mercier et al., 2007b). Lastly, another genetic polymorphism could be a rising concern with capecitabine. Deregulations affecting cytidine deaminase (CDA), one of the three enzymes responsible for the conversion of prodrug capecitabine to 5-FU, could lead to severe toxicities. As for DPD, the gene coding for CDA is highly polymorphic with either loss (poor metabolizer) or gain (ultra-metabolizer, UM) of enzymatic activity. The first life-threatening toxicity in a patient displaying the UM phenotype was reported in the late 2000's (Mercier C et al., 2009). The role CDA could play in severe toxicities with capecitabine has been next confirmed in another larger study showing that deletion in the promoter region of the CDA gene with increased transcription was a predictive marker for hand-foot syndrome (Caronia et al., 2011). Lastly, the first toxic-death case in a capecitabine-treated patient harboring several polymorphisms on the CDA gene, including the Caronia deletion, has been published recently (Dahan et al., 2011), thus highlighting the fact that beside DPYD, other genetic polymorphisms should be screened to ensure a better safety when handling oral fluoropyrimidines.

\subsubsection{Irinotecan}

Irinotecan is a prodrug that can be either metabolized by the Cyp3A sub-family to form the inactive APC derivative, or be converted by carboxylesterase into SN38, a highly cytotoxic metabolite responsible for both the efficacy and the toxicity of irinotecan. SN38 is next mainly detoxified after conjugation by the UGT1A1 to yield inactive SN-38G that will be excreted by the kidneys and the bile eventually. Numerous polymorphisms have been described for the gene coding for UGT1A1, and variations in the promoter region consisting in 7 instead of 6 TA-repeats (UGT1A1*28) is admittedly associated with increased risk of severe toxicities in mCRC patients administered with high dose (e.g., above $250 \mathrm{mg} / \mathrm{m}^{2}$ ) irinotecan (Kweekel et al., 2010). A strong influence of ethnicity has been observed with this allelic variant because its population frequency is as high as $43 \%$ heterozygotes in the Caucasians but much lower in the Asians (Innocenti et al., 2005; deJong et al., 2006). Several independent studies have demonstrated how individuals with the UGT1A1*28 genotype were up to 7-time more at risk to experience haematological or gastrointestinal severe toxicities when treated with irinotecan (Ando et al., 2000; Marcuello et al., 2004). Of note, some authors have reported an association between the UGT1A1*28 genotype and irinotecan efficacy (Toffoli et al., 2006), although other studies have failed in providing evidence for such a relationship (Kweekel et al., 2008). Along with the UGT1A1*28 genotype, other variations such has the UGT1A1*6 most frequently found in Asian populations has been associated with increased severe neutropenia after irinotecan intake (Han et al., 2006), although other studies failed in confirming such relationship (Ando et al., 2000). Additionally, polymorphisms affecting transmembrane pumps involved in the excretion of toxic metabolites could be related to drug resistance. Pharmacogenetics of the ATP-binding cassette proteins has been associated with changes in the pharmacokinetics of irinotecan, because they impact of the renal clearance of the drug and ultimatelly on 
exposure levels. For instance, patients harboring the 34A>G SNP on the ABCG2 gene could be more at risk of treatment failure, as compared with WT patients (Mc Leod et al., 2008). Conversely, other SNPs like the $421 \mathrm{C}>\mathrm{A}$ polymorphism seems to have limited impact on irinotecan pharmacokinetics and clinical outcome (de jong et al., 2004) whereas some mutations were associated with higher incidence of drug-induced toxicities (Cha et al., 2009).

\subsection{Pharmacokinetics of targeted therapies: The hidden biomarker?}

For years, the importance of pharmacokinetic issues such as residual plasma levels or drug concentrations at the tumor site has been largely underestimated with targeted therapies. For instance, it took 5 years since its first approval in Chronic Myeloid Leukemia to acknowledge the fact that the residual concentrations of imatinib were predictive for the major molecular response in patients, thus highlighting the utility to perform drug monitoring and subsequently developing dose-tailoring strategies to ensure a better efficacy (Egorin et al., 2009). Although similar strategies are now developed with other small molecules such as pazopanib (Suttle et al., 2010), no such trend is currently proposed with monoclonal antibodies, despite the fact that dose/exposure/efficacy and dose/exposure/toxicities relationships have been described (Lu et al., 2009, Keiser et al., 2010). Both non-clinical and clinical studies suggest that $90 \%$ of target inhibition should be continuously achieved to ensure a maximum efficacy, thus stressing the usefulness to monitor residual concentrations of monoclonal antibodies such as panitumumab, as for other target therapies (Yang et al., 2010). For instance, plasma residual concentrations of 10$30 \mathrm{ug} / \mathrm{ml}$ are considered necessary with bevacizumab for an optimal efficacy (Data on File Genentech Inc). However, little is known about the pharmacokinetics of monoclonal antibodies and there is a clear lack for markers of inter-patient variability. Proteolytic degradation along with target-mediated drug disposition are the main patterns implicated in the clearance of monoclonal antibodies, and several factors such as antibodies antitherapeutic antibodies, target expression, number of metastatic sites or inflammatory syndromes are likely to modify drug levels in plasma. Of note, genetic polymorphism affecting immunoglobulin $G$ fragment receptor $F_{c}-\gamma-R$ has been identified as a putative marker for rituximab clearance, but the clinical importance of $F c-\gamma-R$ genotype could be more related to the Antibody-Dependent Cell Cytotoxicity (ADCC) of rituximab that involves $F_{C}-\gamma-R$, rather than a pharmacokinetics issue (Cartron et al., 2002). In digestive oncology, Fc- $\gamma$-R genotype has been identified in mCRC patients treated with cetuximab as predictive for PFS, but as for rituximab, this could be related to changes in the ADCC described sometimes with cetuximab rather than changes in pharmacokinetics (Zhang et al., 2007), and other studies failed in confirming the impact this polymorphism could have with the anti-EGFR therapy (Graziano et al., 2008).

\section{Conclusions: One patient, one disease, one drug, one dosage.... Can we finally do it?}

Developing strategies to implement personalized medicine in digestive oncology is now an irreversible trend (Ciccolini et al., 2011). However, identifying predictive biomarkers associated with either treatment efficacy or tolerance remains an uneasy task, because CRC patients are usually treated with up to 6 different drugs in combination over several lines. 
Consequently, and despite the abundant literature published, the heterogeneity in the clinical settings can hinder the relevance of some markers, thus preventing standardized guidelines to be issued. However, oncogenetic, pharmacogenetic and pharmacogenomic tools are now developed as a new mean to help oncologists to choose the optimal strategy for each patient, regarding the staging of the disease, the status of the various response markers, and eventually information about specificities in pharmacokinetics and detoxification patterns, once the right drugs have been chosen. However, this later and critical step remains today the forgotten item in routine clinical setting. Although implementing KRAS pharmacogenomic testing is now a systematic practice prior to administrate cetuximab or panitumumab to mCRC patients, little is done to further develop pharmacogenetics-based dose tailoring strategies to reach next the right exposure likely to ensure an optimal efficacy/toxicity balance. Screening for DPYD or UGT1A1 genetic polymorphisms, despite countless clinical reports demonstrating their role in lifethreatening toxicities, and therefore the usefulness of preliminary testing in patients undergoing 5-FU, capecitabine or irinotecan-based regimen to anticipate treatment-related toxicities, is far from being a common practice. However, when performed, pharmacoeconomic studies suggest that implementation of such screening is cost-effective, thus suggesting that routine pharmacogenetics should benefit both to the patients and to the institute ultimately, by dramatically cutting the costs dedicated to managing the treatmentrelated toxicities (Mercier et al., 2009). Of note, no regulatory official step has been undertaken to date to prompt oncologists to require such tests when prescribing cytotoxics to mCRC patients. Changes in the drug label informing physicians about the toxic risks with irinotecan related to the UGT1A1 genetic polymorphism has been done by the F.D.A in the mid-2000's and official warning issued as a as level-2 priority, but with little impact in clinical practice, partly because the UGT1A1 test is not reimbursed in the U.S. by most insurance companies (Ikediobi et al., 2009, Meckley et al. 2010), and partly because of the lack of tools to customize the irinotecan dosage once the UGT1A1 status has been obtained. As of today, it is acknowledged that the UGT1A1*28 genotype is a concern in patients scheduled for irinotecan dosage above $200 \mathrm{mg} / \mathrm{m}^{2}$ only, with little further guidelines made available about adaptive dosing strategies to treat patients harboring this polymorphism (Hoskins et al., 2007) because. Usually, an empirical 25-50\% reduction in irinotecan starting dose is recommended in patients with the homozygous variant. Similarly, screening for DPYD genetic polymorphism is an exceptional, rather than a routine test in most institutes. DPD testing can be required at best once the severe toxicities have already shown in a patient treated with a 5-FU-containing regimen to keep or discard the fluoropyrimidine in the forthcoming course. As for UGT1A1, little tools are available to tailor dosage based upon the DPD status of the patient. However, a case-control study has demonstrated the immediate advantages patients could benefit from prospective DPD testing associated with adaptive-dosing, with a sharp reduction in the incidence of 5-FU-related toxicities in patients screened for DPD deficiency with tailored dosage as compared with patients treated with standard regimen (Yang et al., 2009). Of note, efficacy remained the same in this study despite markedly lower doses in patients with DPD deficiency, thus illustrating how pharmacogenetics-based adaptive dosing could improve indeed the efficacy/toxicity balance of canonical 5-FU. In this respect, prospective clinical trials investigating pharmacogenetics of drugs given in mCRC patients with strong PK, PK/PD and 
PK/PD/PGx modeling support should help to develop easy-to-implement tools designed to individualize dosing based upon the patients genotypes or phenotypes.

\section{References}

Amstutz U, \& Carleton BC. (2011). Pharmacogenetic testing: time for clinical practice guidelines. Clin Pharmacol Ther, Vol. 89, N6, pp.924-7.

Ando Y, Saka H, Ando M, Sawa T, Muro K, Ueoka H, Yokoyama A, Saitoh S, Shimokata K, \& Hasegawa Y. (2000). Polymorphisms of UDP-glucuronosyltransferase gene and irinotecan toxicity: a pharmacogenetic analysis. Cancer Res, Vol. 60, N²4, pp.6921-6.

Asghar U, Hawkes E, \& Cunningham D. (2010) Predictive and prognostic biomarkers for targeted therapy in metastatic colorectal cancer. Clin Colorectal Cancer, Vol. 9, No5, pp.274-81.

Backus HH, Dukers DF, van Groeningen CJ, Vos W, Bloemena E, Wouters D, van Riel JM, Smid K, Giaccone G, Pinedo HM, \& Peters GJ. (2011) 5-Fluorouracil induced Fas upregulation associated with apoptosis in liver metastases of colorectal cancer patients. Ann Oncol, Vol. 12, N², pp.209-16.

Batchelor T, et al. (2007). AZD 2171, a pan-VEGF receptor tyrosine kinase inhibitor, normalizes tumor vasculature and alleviates edema in glioblastoma patients. Cancer Cell, Vol. 11, Nº6, pp.83-95.

Bezulier K, Fina F, Roussel M, Bun SS, Ciccolini J, Martin PM, Milano G, Aubert C, \& Barra Y. (2003). Fas/FasL expression in tumor biopsies: a prognostic response factor to fluoropyrimidines? J Clin Pharm Ther, Vol. 28, N5, pp.403-8.

Borralho PM, Moreira da Silva IB, Aranha MM, Albuquerque C, Nobre Leitão C, Steer CJ, \& Rodrigues CM. (2007). Inhibition of Fas expression by RNAi modulates 5fluorouracil-induced apoptosis in HCT116 cells expressing wild-type p53. Biochim Biophys Acta, Vol. 1772, N¹, pp.40-7.

Braun MS, Richman SD, Thompson L, Daly CL, Meade AM, Adlard JW, Allan JM, Parmar MK, Quirke P, \& Seymour MT. (2009). Association of molecular markers with toxicity outcomes in a randomized trial of chemotherapy for advanced colorectal cancer: the FOCUS trial. J Clin Oncol, Vol. 27, N³3, pp.5519-28.

Caronia D, Martin M, Sastre J, de la Torre J, García-Sáenz JA, Alonso MR, Moreno LT, Pita G, Díaz-Rubio E, Benítez J, \& González-Neira A. (2006). A polymorphism in the cytidine deaminase promoter predicts severe capecitabine-induced hand-foot syndrome. Clin Cancer Res, Vol. 17, N7, pp.2006-13

Cartron G, Dacheux L, Salles G, Solal-Celigny P, Bardos P, Colombat P, \& Watier H. (2002). Therapeutic activity of humanized anti-CD20 monoclonal antibody and polymorphism in IgG Fc receptor FcgammaRIIIa gene. Blood, Vol. 99, N³, pp.754-8.

Cha PC, Mushiroda T, Zembutsu H, Harada H, Shinoda N, Kawamoto S, Shimoyama R, Nishidate T, Furuhata T, Sasaki K, Hirata K, \& Nakamura Y. (2009). Single nucleotide polymorphism in ABCG2 is associated with irinotecan-induced severe myelosuppression. J Hum Genet, Vol. 54, Nº10, pp.572-80.

Ciccolini J, Peillard L, Aubert C, Formento P, Milano G, \& Catalin J. (2000a). Monitoring of the intracellular activation of 5-fluorouracil to deoxyribonucleotides in HT29 human colon cell line: application to modulation of metabolism and cytotoxicity study. Fundam Clin Pharmacol, Vol. 14, N², pp.147-54. 
Ciccolini J, Peillard L, Evrard A, Cuq P, Aubert C, Pelegrin A, Formento P, Milano G, \& Catalin J. (2000b). Enhanced antitumor activity of 5-fluorouracil in combination with 2'-deoxyinosine in human colorectal cell lines and human colon tumor xenografts. Clin Cancer Res, Vol. 6, N²4, pp.1529-35.

Ciccolini J, Cuq P, Evrard A, Giacometti S, Pelegrin A, Aubert C, Cano JP, \& Iliadis A. (2001). Combination of thymidine phosphorylase gene transfer and deoxyinosine treatment greatly enhances 5-fluorouracil antitumor activity in vitro and in vivo. Mol Cancer Ther, Vol. 1, N², pp.133-9.

Ciccolini J, Evrard A, \& Cuq P. (2004). Thymidine phosphorylase and fluoropyrimidines efficacy: a Jekyll and Hyde story. Curr Med Chem Anticancer Agents, Vol. 4, N², pp.71-81.

Ciccolini J, Mercier C, Evrard A, Dahan L, Boyer JC, Duffaud F, Lacarelle B, \& Seitz JF. (2006). A rapid and inexpensive method for anticipating severe toxicity to fluorouracil and fluorouracil-based chemotherapy. Ther Drug Monit, Vol. 28, pp.678-85.

Ciccolini J, Mercier C, Dahan L, \& André N. (2011). Integrating pharmacogenetics into gemcitabine dosing-Time for a change? Nat Rev Clin Oncol, Vol. 8, N7, pp.439-44.

Crawford Y, Kasman I, Yu L, Zhong C, Wu X, Modrusan Z, Kaminker J, \& Ferrara N. (2009). PDGF-C mediates the angiogenic and tumorigenic properties of fibroblasts associated with tumors refractory to anti-VEGF treatment. Cancer Cell, Vol. 15, N¹, pp.21-34.

Dahan L, Ciccolini J, Evrard A, Mbatchi L, Tibbits J, Ries P, Norguet E, Mercier C, Iliadis A, Ouafik LH, Lacarelle B, \& Seitz JF. (2011) Sudden toxic-death in a patient upon Xeliri (capecitabine + irinotecan) plus bevacizumab intake: pharmacogenetics implications. J Clin Oncol, Vol. 29, E-Pub ahead of Print.

de Jong FA, Marsh S, Mathijssen RH, King C, Verweij J, Sparreboom A, \& McLeod HL. (2004). ABCG2 pharmacogenetics: ethnic differences in allele frequency and assessment of influence on irinotecan disposition. Clin Cancer Res, Vol. 10, Nº17, pp.5889-94.

de Jong FA, Kehrer DF, Mathijssen RH, Creemers GJ, de Bruijn P, van Schaik RH, Planting AS, van der Gaast A, Eskens FA, Janssen JT, Ruit JB, Verweij J, Sparreboom A, \& de Jonge MJ. (2006). Prophylaxis of irinotecan-induced diarrhea with neomycin and potential role for UGT1A1*28 genotype screening: a double-blind, randomized, placebo-controlled study. Oncologist, Vol. 11, N8, pp.944-54.

Di Fiore F, Sesboüé R, Michel P, Sabourin JC, \& Frebourg T. (2010). Molecular determinants of anti-EGFR sensitivity and resistance in metastatic colorectal cancer. $\mathrm{Br}$ J Cancer, Vol. 103, N¹2, pp.1765-72

Di Nicolantonio F, Martini M, Molinari F, Sartore-Bianchi A, Arena S, Saletti P, De Dosso S, Mazzucchelli L, Frattini M, Siena S, \& Bardelli A. (2008). Wild-type BRAF is required for response to panitumumab or cetuximab in metastatic colorectal cancer. J Clin Oncol, Vol. 26, N³5, pp.5705-12.

Dotor E, Cuatrecases M, Martínez-Iniesta M, Navarro M, Vilardell F, Guinó E, Pareja L, Figueras A, Molleví DG, Serrano T, de Oca J, Peinado MA, Moreno V, Germà JR, Capellá G, \& Villanueva A. (2006). Tumor thymidylate synthase 1494del6 genotype as a prognostic factor in colorectal cancer patients receiving fluorouracil-based adjuvant treatment. J Clin Oncol, Vol. 249, N¹0, pp.1603-11. 
Edler D, Glimelius B, Hallström M, Jakobsen A, Johnston PG, Magnusson I, Ragnhammar P, \& Blomgren H. (2002). Thymidylate synthase expression in colorectal cancer: a prognostic and predictive marker of benefit from adjuvant fluorouracil-based chemotherapy. J Clin Oncol, Vol. 20, N7, pp.1721-8.

Egorin MJ, Mauro MJ, \& Trent JC.(2009). Drug plasma monitoring in CML and GIST: A case-based discussion. Clin Adv Hematol Oncol, Vol. 7, Nº11-S1, pp. S3-11.

Etienne MC, Lagrange JL, Dassonville O, Fleming R, Thyss A, Renee N, \& Milano G. (1994). Population study of dihydropyrimidine dehydrogenase in cancer patients. J Clin Oncol, Vol. 12, N¹1, pp.2248-53.

Etienne-Grimaldi MC, Formento P, Degeorges A, Pierga JY, Delva R, Pivot X, Dalenc F, Espié M, Veyret C, Formento JL, Francoual M, Piutti M, de Crémoux P, \& Milano G. (2011). Prospective analysis of the impact of VEGF-A gene polymorphisms on pharmacodynamics of bevacizumab-based therapy in metastatic breast cancer patients. Br J Clin Pharmacol, Vol. 71, N6, pp.921-8

Etienne-Grimaldi MC, Francoual M, Formento JL, \& Milano G. (2007). Methylenetetrahydrofolate reductase (MTHFR) variants and fluorouracil-based treatments in colorectal cancer. Pharmacogenomics, Vol. 8, Nº11, pp.1561-6.

Fanciullino R, Evrard A, Cuq P, Giacometti S, Peillard L, Mercier C, Aubert C, Milano G, \& Ciccolini J. (2006). Genetic and biochemical modulation of 5-fluorouracil through the overexpression of thymidine kinase: an in-vitro study. Anticancer Drugs, Vol. 17, $\mathrm{N}^{\circ} 4$, pp.463-70

Formica V, Palmirotta R, Del Monte G, Savonarola A, Ludovici G, De Marchis ML, Grenga I, Schirru M, Guadagni F, \& Roselli M. Predictive value of VEGF gene polymorphisms for metastatic colorectal cancer patients receiving first-line treatment including fluorouracil, irinotecan, and bevacizumab. Int J Colorectal Dis, Vol. 26, N², pp.143-51.

Frattini M, Saletti P, Romagnani E, Martin V, Molinari F, Ghisletta M, Camponovo A, Etienne LL, Cavalli F, \& Mazzucchelli L. (2007). PTEN loss of expression predicts cetuximab efficacy in metastatic colorectal cancer patients. Br J Cancer, Vol. 97, $\mathrm{N}^{\circ} 8$, pp.1139-45.

Gamelin L, Capitain O, Morel A, Dumont A, Traore S, Anne le B, Gilles S, Boisdron-Celle M, \& Gamelin E. (2007). Predictive factors of oxaliplatin neurotoxicity: the involvement of the oxalate outcome pathway. Clin Cancer Res, Vol. 13, N²1, pp.6359-68.

Glasgow SC, Yu J, Carvalho LP, Shannon WD, Fleshman JW, \& McLeod HL. (2005). Unfavourable expression of pharmacologic markers in mucinous colorectal cancer. Br J Cancer, Vol. 92, N², pp.259-64.

Graziano F, Ruzzo A, Loupakis F, Canestrari E, Santini D, Catalano V, Bisonni R, Torresi U, Floriani I, Schiavon G, Andreoni F, Maltese P, Rulli E, Humar B, Falcone A, Giustini L, Tonini G, Fontana A, Masi G, \& Magnani M. (2008). Pharmacogenetic profiling for cetuximab plus irinotecan therapy in patients with refractory advanced colorectal cancer. J Clin Oncol, Vol. 26, N9, pp.1427-34.

Han JY, Lim HS, Shin ES, Yoo YK, Park YH, Lee JE, Jang IJ, Lee DH, \& Lee JS. (2006). Comprehensive analysis of UGT1A polymorphisms predictive for pharmacokinetics and treatment outcome in patients with non-small-cell lung cancer treated with irinotecan and cisplatin. J Clin Oncol, Vol. 24, Nº11, pp.2237-44. 
Heinemann V, Stintzing S, Kirchner T, Boeck S, \& Jung A. (2009). Clinical relevance of EGFR- and KRAS-status in colorectal cancer patients treated with monoclonal antibodies directed against the EGFR. Cancer Treat Rev, Vol. 35, N³, pp.262-71

Hoskins JM, Goldberg RM, Qu P, Ibrahim JG, \& McLeod HL. (2007). UGT1A1²8 genotype and irinotecan-induced neutropenia: dose matters. J Natl Cancer Inst, Vol. 99, Nº7, pp.1290-5

Hoskins JM, Marcuello E, Altes A, Marsh S, Maxwell T, Van Booven DJ, Paré L, Culverhouse R, McLeod HL, \& Baiget M. (2008). Irinotecan pharmacogenetics: influence of pharmacodynamic genes. Clin Cancer Res, Vol. 14, Nº, pp.1788-96.

Ikediobi ON, Shin J, Nussbaum RL, Phillips KA; UCSF Center for Translational and Policy Research on Personalized Medicine, Walsh JM, Ladabaum U, \& Marshall D. (2009). Addressing the challenges of the clinical application of pharmacogenetic testing. Clin Pharmacol Ther, Vol. 86, Nº1, pp.28-31.

Innocenti F, Liu W, Chen P, Desai AA, Das S, \& Ratain MJ. (2005). Haplotypes of variants in the UDP-glucuronosyltransferase1A9 and 1A1 genes. Pharmacogenet Genomics, Vol. 15, N5, pp.295-301.

Jacobs B, De Roock W, Piessevaux H, Van Oirbeek R, Biesmans B, De Schutter J, Fieuws S, Vandesompele J, Peeters M, Van Laethem JL, Humblet Y, Pénault-Llorca F, De Hertogh G, Laurent-Puig P, Van Cutsem E, \& Tejpar S. (2009). Amphiregulin and epiregulin mRNA expression in primary tumors predicts outcome in metastatic colorectal cancer treated with cetuximab. J Clin Oncol, Vol. 27, N¹3, pp.5068-74

Jakobsen A, Nielsen JN, Gyldenkerne N, \& Lindeberg J. (2005). Thymidylate synthase and methylenetetrahydrofolate reductase gene polymorphism in normal tissue as predictors of fluorouracil sensitivity. J Clin Oncol, Vol. 23, N², pp.1365-9.

Keizer RJ, Huitema AD, Schellens JH, \& Beijnen JH. (2010). Clinical pharmacokinetics of therapeutic monoclonal antibodies. Clin Pharmacokinet, Vol. 49, Nº8, pp.493-507.

Kim JG, Sohn SK, Chae YS, Cho YY, Bae HI, Yan G, Park JY, Lee MH, Chung HY, \& Yu W. (2007). Vascular endothelial growth factor gene polymorphisms associated with prognosis for patients with gastric cancer. Ann Oncol, Vol. 18, Nº6, pp.1030-6.

Kopetz S, Hoff PM, Morris JS, Wolff RA, Eng C, Glover KY, Adinin R, Overman MJ, Valero V, Wen S, Lieu C, Yan S, Tran HT, Ellis LM, Abbruzzese JL, \& Heymach JV. (2010). Phase II trial of infusional fluorouracil, irinotecan, and bevacizumab for metastatic colorectal cancer: efficacy and circulating angiogenic biomarkers associated with therapeutic resistance. J Clin Oncol, Vol. 28, N³, pp.453-9.

Kostopoulos I, Karavasilis V, Karina M, Bobos M, Xiros N, Pentheroudakis G, Kafiri G, Papakostas P, Vrettou E, \& Fountzilas G. (2009). Topoisomerase I but not thymidylate synthase is associated with improved outcome in patients with resected colorectal cancer treated with irinotecan containing adjuvant chemotherapy. BMC Cancer, 2009 Sep 24; 9:339.

Koutras AK, Starakis I, Kyriakopoulou U, Katsaounis P, Nikolakopoulos A, \& Kalofonos HP. (2011). Targeted therapy in colorectal cancer: current status and future challenges. Curr Med Chem, Vol. 18, N¹1, pp.1599-612.

Kweekel DM, Gelderblom H, \& Guchelaar HJ. (2005). Pharmacology of oxaliplatin and the use of pharmacogenomics to individualize therapy. Cancer Treat Rev, Vol. 31, N², pp. $90-105$. 
Kweekel DM, Gelderblom H, Van der Straaten T, Antonini NF, Punt CJ, \& Guchelaar HJ; Dutch Colorectal Cancer Group study.(2008). UGT1A1*28 genotype and irinotecan dosage in patients with metastatic colorectal cancer: a Dutch Colorectal Cancer Group study. Br J Cancer, Vol. 99, N², pp.275-82

Labianca R, \& Merelli B. (2010). Screening and diagnosis for colorectal cancer: present and future. Tumori, Vol. 96, Nº, pp.889-901.

Largillier R, Etienne-Grimaldi MC, Formento JL, Ciccolini J, Nebbia JF, Ginot A, Francoual M, Renée N, Ferrero JM, Foa C, Namer M, Lacarelle B, \& Milano G. (2006). Pharmacogenetics of capecitabine in advanced breast cancer patients. Clin Cancer Res, Vol. 12, N¹8, pp.5496-502.

Laurent-Puig P, Cayre A, Manceau G, Buc E, Bachet JB, Lecomte T, Rougier P, Lievre A, Landi B, Boige V, Ducreux M, Ychou M, Bibeau F, Bouché O, Reid J, Stone S, \& Penault-Llorca F. (2009). Analysis of PTEN, BRAF, and EGFR status in determining benefit from cetuximab therapy in wild-type KRAS metastatic colon cancer. J Clin Oncol, Vol. 27, N³5, pp.5924-30.

Laurent-Puig P, Lievre A,\& Blons H. (2009). Mutations and response to epidermal growth factor receptor inhibitors. Clin Cancer Res, Vol. 15, N4, pp.1133-9.

Le Morvan V, Smith D, Laurand A, Brouste V, Bellott R, Soubeyran I, Mathoulin-Pelissier S, \& Robert J. (2007). Determination of ERCC2 Lys751Gln and GSTP1 Ile105Val gene polymorphisms in colorectal cancer patients: relationships with treatment outcome. Pharmacogenomics, Vol. 8, N¹2, pp.1693-703.

Lenz HJ. (2004). Pharmacogenomics and colorectal cancer. Ann Oncol, Vol. 15, NºS4:iv, pp.173-7

Lièvre A, Bachet JB, Le Corre D, Boige V, Landi B, Emile JF, Côté JF, Tomasic G, Penna C, Ducreux M, Rougier P, Penault-Llorca F, \& Laurent-Puig P. (2006). KRAS mutation status is predictive of response to cetuximab therapy in colorectal cancer. Cancer Res, Vol. 66, N8, pp.3992-5.

Locker GY, Hamilton S, Harris J, Jessup JM, Kemeny N, Macdonald JS, Somerfield MR, Hayes DF, \& Bast RC. (2006). ASCO 2006 update of recommendations for the use of tumor markers in gastrointestinal cancer. J Clin Oncol, Vol. 24, N³3, pp.5313-27.

Lu H, Shu XO, Cui Y, Kataoka N, Wen W, Cai Q, Ruan ZX, Gao YT, \& Zheng W. (2005). Association of genetic polymorphisms in the VEGF gene with breast cancer survival. Cancer Res, Vol. 65, N¹2, pp.5015-9.

Lu JF, Bruno R, Eppler S, Novotny W, Lum B, \& Gaudreault J. (2008). Clinical pharmacokinetics of bevacizumab in patients with solid tumors. Cancer Chemother Pharmacol, Vol. 62, N5, pp.779-86

Lurje G, Manegold PC, Ning Y, Pohl A, Zhang W, \& Lenz HJ. (2009). Thymidylate synthase gene variations: predictive and prognostic markers. Mol Cancer Ther, Vol. 8, No5, pp.1000-7.

Marcuello E, Altés A, Menoyo A, Del Rio E, Gómez-Pardo M, \& Baiget M. (2004). UGT1A1 gene variations and irinotecan treatment in patients with metastatic colorectal cancer. Br J Cancer, Vol. 91, N4, pp. 678-82.

Meckley LM, Neumann PJ. (2010) Personalized medicine: factors influencing reimbursement. Health Policy, Vol.94, N², pp.91-100. 
Mercier C, \& Ciccolini J. (2006). Profiling dihydropyrimidine dehydrogenase deficiency in patients with cancer undergoing 5-fluorouracil/capecitabine therapy. Clin Colorectal Cancer, Vol. 6, Nº4, pp. 288-96.

Mercier C, Raynal C, Dahan L, Ortiz A, Evrard A, Dupuis C, Blesius A, Duluc M, Franceschini F, Giacometti S, Salas S, Milano G, Favre R, Seitz JF, \& Ciccolini J. (2007a). Toxic death case in a patient undergoing gemcitabine-based chemotherapy in relation with cytidine deaminase downregulation. Pharmacogenet Genomics, Vol. $17, \mathrm{~N}^{\circ} 10, \mathrm{pp} .841-4$.

Mercier C, \& Ciccolini J. (2007b). Severe or lethal toxicities upon capecitabine intake: is DPYD genetic polymorphism the ideal culprit? Trends Pharmacol.Sci, Vol. 28, N²12, pp. 597-8.

Mercier C, Brunet C, Yang C, Dupuis C, Bagarry-Liegey D, Duflo S, Giovanni A, Zanaret M, Lacarelle B, Duffaud F, \& Ciccolini J. (2009). Pharmacoeconomic study in head and neck cancer patients: Impact of prospective DPD deficiency screening with 5fluorouracil (5-FU) dose tailoring on toxicities-related costs. J Clin Oncol, Vol. 27, $\mathrm{N}^{\circ} 15 \mathrm{~s}$, (suppl; abstr 6515).

Morel A, Boisdron-Celle M, Fey L, Soulie P, Craipeau MC, Traore S \& Gamelin E. (2006). Clinical relevance of different dihydropyrimidine dehydrogenase gene single nucleotide polymorphisms on 5-fluorouracil tolerance. Mol Cancer Ther, Vol. 5, $\mathrm{N}^{\circ} 11$, pp. 2895-904.

Moroni M, Veronese S, Benvenuti S, Marrapese G, Sartore-Bianchi A, Di Nicolantonio F, Gambacorta M, Siena S, \& Bardelli A. (2005). Gene copy number for epidermal growth factor receptor (EGFR) and clinical response to antiEGFR treatment in colorectal cancer: a cohort study. Lancet Oncol, Vol. 6, N5, pp. 279-86.

Popat S, Matakidou A, \& Houlston RS. (2004). Thymidylate synthase expression and prognosis in colorectal cancer: a systematic review and meta-analysis. J Clin Oncol, Vol. 22, N³, pp. 529-36.

Pullmann R Jr, Abdelmohsen K, Lal A, Martindale JL, Ladner RD, \& Gorospe M. (2006). Differential stability of thymidylate synthase 3'-untranslated region polymorphic variants regulated by AUF1. J Biol Chem, Vol. 281, N³3, pp. 23456-63.

Ruzzo A, Graziano F, Loupakis F, Rulli E, Canestrari E, Santini D, Catalano V, Ficarelli R, Maltese P, Bisonni R, Masi G, Schiavon G, Giordani P, Giustini L, Falcone A, Tonini G, Silva R, Mattioli R, Floriani I, \& Magnani M. (2007). Pharmacogenetic profiling in patients with advanced colorectal cancer treated with first-line FOLFOX-4 chemotherapy. J Clin Oncol, Vol. 25, N¹0, pp. 1247-54.

Salgado J, Zabalegui N, Gil C, Monreal I, Rodríguez J, \& García-Foncillas J. (2007). Polymorphisms in the thymidylate synthase and dihydropyrimidine dehydrogenase genes predict response and toxicity to capecitabine-raltitrexed in colorectal cancer. Oncol Rep, Vol. 17, N², pp. 325-8.

Sartore-Bianchi A, Moroni M, Veronese S, Carnaghi C, Bajetta E, Luppi G, Sobrero A, Barone C, Cascinu S, Colucci G, Cortesi E, Nichelatti M, Gambacorta M, \& Siena S. (2007). Epidermal growth factor receptor gene copy number and clinical outcome of metastatic colorectal cancer treated with panitumumab. J Clin Oncol, Vol. 25, N²2, pp. 3238-45.

Schneider BP, Wang M, Radovich M, Sledge GW, Badve S, Thor A, Flockhart DA, Hancock B, Davidson N, Gralow J, Dickler M, Perez EA, Cobleigh M, Shenkier T, Edgerton S, 
Miller KD; \& ECOG 2100. (2008). Association of vascular endothelial growth factor and vascular endothelial growth factor receptor-2 genetic polymorphisms with outcome in a trial of paclitaxel compared with paclitaxel plus bevacizumab in advanced breast cancer: ECOG 2100. J Clin Oncol, Vol. 26, N²8, pp. 4672-8.

Schwab M, Zanger UM, Marx C, Schaeffeler E, Klein K, Dippon J et al. (2008). Role of genetic and nongenetic factors for fluorouracil treatment-related severe toxicity: a prospective clinical trial by the German 5-FU Toxicity Study Group. J Clin Oncol, Vol. 26, N¹3, pp. 2131-8.

Sharma R, Hoskins JM, Rivory LP, Zucknick M, London R, Liddle C, \& Clarke SJ. (2008). Thymidylate synthase and methylenetetrahydrofolate reductase gene polymorphisms and toxicity to capecitabine in advanced colorectal cancer patients. Clin Cancer Res, Vol. 14, N³, pp. 817-25.

Soong R, Shah N, Salto-Tellez M, Tai BC, Soo RA, Han HC, Ng SS, Tan WL, Zeps N, Joseph D, Diasio RB, \& Lacopetta B. (2008). Prognostic significance of thymidylate synthase, dihydropyrimidine dehydrogenase and thymidine phosphorylase protein expression in colorectal cancer patients treated with or without 5fluorouracil-based chemotherapy. Ann Oncol, Vol. 19, N5, pp. 915-9

Stoehlmacher J, Ghaderi V, Iobal S, Groshen S, Tsao-Wei D, Park D, \& Lenz HJ. (2001). A polymorphism of the XRCC1 gene predicts for response to platinum based treatment in advanced colorectal cancer. Anticancer Res, Vol. 21, N4B, pp. 3075-9.

Stoehlmacher J, Park DJ, Zhang W, Groshen S, Tsao-Wei DD, Yu MC, \& Lenz HJ. (2002). Association between glutathione S-transferase P1, T1, and M1 genetic polymorphism and survival of patients with metastatic colorectal cancer. $J$ Natl Cancer Inst, Vol. 94, N¹2, pp. 936-42.

Stoehlmacher J, Park DJ, Zhang W, Yang D, Groshen S, Zahedy S, \& Lenz HJ. (2004). A multivariate analysis of genomic polymorphisms: prediction of clinical outcome to 5-FU/oxaliplatin combination chemotherapy in refractory colorectal cancer. $\mathrm{Br} \mathrm{J}$ Cancer, Vol. 91, N², pp. 344-54.

Suh KW, Kim JH, Kim do Y, Kim YB, Lee C, \& Choi S. (2006). Which gene is a dominant predictor of response during FOLFOX chemotherapy for the treatment of metastatic colorectal cancer, the MTHFR or XRCC1 gene? Ann Surg Oncol, Vol. 13, $\mathrm{N}^{\circ} 11$, pp. 1379-85.

Sun XF, Ahmadi A, Arbman G, Wallin A, Asklid D, \& Zhang H. (2005). Polymorphisms in sulfotransferase $1 \mathrm{~A} 1$ and glutathione S-transferase P1 genes in relation to colorectal cancer risk and patients' survival. World J Gastroenterol, Vol. 11, №43, pp. 6875-9

Suttle B, Ball HA, Molimard M, Rajagopalan D, Swann S, Amado R, \& Pandite L. (2010). Relationship between exposure to pazopanib and efficacy in patients with advanced renal cell carcinoma. J Clin Oncol Vol. 28, N¹5s (suppl; abstr 3048).

Toffoli G, Cecchin E, Corona G, Russo A, Buonadonna A, D'Andrea M, Pasetto LM, Pessa S, Errante D, De Pangher V, Giusto M, Medici M, Gaion F, Sandri P, Galligioni E, Bonura S, Boccalon M, Biason P, \& Frustaci S. (2006). The role of UGT1A1*28 polymorphism in the pharmacodynamics and pharmacokinetics of irinotecan in patients with metastatic colorectal cancer. J Clin Oncol, Vol. 24, N¹9, pp. 3061-8.

Uetake H, Ichikawa W, Takechi T, Fukushima M, Nihei Z, \& Sugihara K. (1999). Relationship between intratumoral dihydropyrimidine dehydrogenase activity and gene expression in human colorectal cancer. Clin Cancer Res, Vol. 5, ํ10, pp. 2836-9. 
Vallböhmer D, Iqbal S, Yang DY, Rhodes KE, Zhang W, Gordon M, Fazzone W, Schultheis AM, Sherrod AE, Danenberg KD, \& Lenz HJ. (2006). Molecular determinants of irinotecan efficacy. Int J Cancer, Vol. 119, N¹0, pp. 2435-42.

Van Kuilenburg AB. (2004). Dihydropyrimidine dehydrogenase and the efficacy and toxicity of 5-fluorouracil. Eur J Cancer, Vol. 40, N7, pp. 939-50.

Yang BB, Lum P, Chen A, Arends R, Roskos L, Smith B, \& Pérez Ruixo JJ. (2010). Pharmacokinetic and pharmacodynamic perspectives on the clinical drug development of panitumumab. Clin Pharmacokinet, Vol. 49, Nº11, pp.729-40

Yang CG, Ciccolini J, Blesius A, Dahan L, Bagarry-Liegey D, Brunet C, Varoquaux A, Frances N, Marouani H, Giovanni A, Ferri-Dessens RM, Chefrour M, Favre R, Duffaud F, Seitz JF, Zanaret M, Lacarelle B, \& Mercier C. (2011). DPD-based adaptive dosing of 5-FU in patients with head and neck cancer: impact on treatment efficacy and toxicity. Cancer Chemother Pharmacol, Vol. 67, Nº1, pp. 49-56.

Zhang W, Gordon M, Schultheis AM, Yang DY, Nagashima F, Azuma M, Chang HM, Borucka E, Lurje G, Sherrod AE, Iqbal S, Groshen S, \& Lenz HJ. (2007). FCGR2A and FCGR3A polymorphisms associated with clinical outcome of epidermal growth factor receptor expressing metastatic colorectal cancer patients treated with single-agent cetuximab. J Clin Oncol, Vol. 25, N²4, pp. 3712-8.

Zhang X, Li L, Fourie J, Davie JR, Guarcello V, \& Diasio RB. (2006). The role of Sp1 and Sp3 in the constitutive DPYD gene expression. Biochim Biophys Acta, Vol. 1759, No5, pp. 247-56.

Zintzaras E, Ziogas DC, Kitsios GD, Papathanasiou AA, Lau J, \& Raman G. (2009). MTHFR gene polymorphisms and response to chemotherapy in colorectal cancer: a metaanalysis. Pharmacogenomics, Vol. 10, N8, pp. 1285-94. 


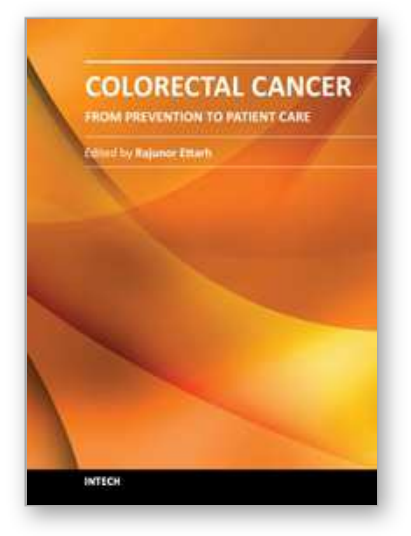

\author{
Colorectal Cancer - From Prevention to Patient Care \\ Edited by Dr. Rajunor Ettarh
}

ISBN 978-953-51-0028-7

Hard cover, 538 pages

Publisher InTech

Published online 17, February, 2012

Published in print edition February, 2012

The projections for future growth in the number of new patients with colorectal cancer in most parts of the world remain unfavorable. When we consider the substantial morbidity and mortality that accompanies the disease, the acute need for improvements and better solutions in patient care becomes evident. This volume, organized in five sections, represents a synopsis of the significant efforts from scientists, clinicians and investigators towards finding improvements in different patient care aspects including nutrition, diagnostic approaches, treatment strategies with the addition of some novel therapeutic approaches, and prevention. For scientists involved in investigations that explore fundamental cellular events in colorectal cancer, this volume provides a framework for translational integration of cell biological and clinical information. Clinicians as well as other healthcare professionals involved in patient management for colorectal cancer will find this volume useful.

\title{
How to reference
}

In order to correctly reference this scholarly work, feel free to copy and paste the following:

Joseph Ciccolini, Fréderic Fina, L'Houcine Ouafik and Bruno Lacarelle (2012). Pharmacogenetics and Pharmacogenomics of Colorectal Cancer: Moving Towards Personalized Medicine, Colorectal Cancer - From Prevention to Patient Care, Dr. Rajunor Ettarh (Ed.), ISBN: 978-953-51-0028-7, InTech, Available from: http://www.intechopen.com/books/colorectal-cancer-from-prevention-to-patient-care/pharmacogeneticspharmacogenomics-of-colorectal-cancer-moving-towards-personalized-medicine

\section{INTECH}

open science | open minds

\section{InTech Europe}

University Campus STeP Ri

Slavka Krautzeka 83/A

51000 Rijeka, Croatia

Phone: +385 (51) 770447

Fax: +385 (51) 686166

www.intechopen.com

\section{InTech China}

Unit 405, Office Block, Hotel Equatorial Shanghai

No.65, Yan An Road (West), Shanghai, 200040, China

中国上海市延安西路65号上海国际贵都大饭店办公楼 405 单元

Phone: +86-21-62489820

Fax: $+86-21-62489821$ 
(C) 2012 The Author(s). Licensee IntechOpen. This is an open access article distributed under the terms of the Creative Commons Attribution 3.0 License, which permits unrestricted use, distribution, and reproduction in any medium, provided the original work is properly cited. 